Pesq. Vet. Bras. 38(1):167-174, janeiro 2018

\title{
Analysis of the reproductive stage and ovarian histomorphometry of Dermanura cinerea (Chiroptera: Phyllostomidae) in an Atlantic Forest fragment of Pernambuco, northeastern Brazil ${ }^{1}$
}

\author{
Nivaldo B. Lima Junior ${ }^{2 *}$, Maria J.G. Arandas², Fabricya R. Silva², Erivaldo A. \\ Antonio $^{2}$, Francisco C.A. Aguiar Júnior ${ }^{3}$, Álvaro A.C. Teixeira² ${ }^{2}$ José E. Garcia ${ }^{3}$ \\ and Katharine R.P. Santos ${ }^{3}$
}

\begin{abstract}
Lima Junior N.B., Arandas M.J.G., Silva F.R., Antonio E.A., Aguiar Júnior F.C.A., Teixeira A.A.C., Garcia J.E. \& Santos K.R.P. 2018. Analysis of the reproductive stage and ovarian histomorphometry of Dermanura cinerea (Chiroptera: Phyllostomidae) in an Atlantic Forest fragment of Pernambuco, northeastern Brazil. Pesquisa Veterinária Brasileira 38(1):167-174. Área de Morfologia, Departamento de Morfologia e Fisiologia Animal, Universidade Federal Rural de Pernambuco, Rua Dom Manoel de Medeiros s/n, Dois Irmãos, Recife, PE 52171-900, Brazil. E-mail: nivaldobernardo@hotmail.com

This study aimed to analyze the reproductive stage, histology and morphometry of the ovary of Dermanura cinerea in an Atlantic Forest fragments in the Biological Reserve of Saltinho, Pernambuco, Brazil. Adult females were captured monthly by mist net, during two consecutive nights from June/2014 to November/2015. The meteorological data were provided by the National Institute of Meteorology and grouped together with the reproductive data, in six periods: period I (June to August/2014), period II (September to November/2014), period III (December/2014 to February/2015), period IV (March to May/2015), period V (June to August/2015) and period VI (September to November/2015). The females were classified according to their reproductive stages in: Inactive, pregnant, lactating and postlactating. Among the 25 females caught, 10 inactive females were selected for the histomorphometric analysis of the ovaries and then they were euthanized. After that, the specimens had their ovaries removed, fixed, processed and included in Paraplast. The organs were cut and stained by Hematoxylin - Eosin and the histological slides produced were submitted to the appropriate optical microscope analysis. Each type of ovarian follicle was estimated according to the histological characteristics evidenced for other mammals. In the morphometric analysis, it was considered: The area of the ovary (measured in square millimeter), Quantification of different types of ovarian follicles (unilaminar and multilaminar primary follicles, antral and matures) and corpus luteum, as well as the area of each by those different follicles (measured in square micrometer) The results indicated that 16 females were inactive, 5 were lactating, 4 were pregnant and no post-lactating. The histological analysis revealed that the ovaries of $D$. cinerea exhibit characteristics, structures and cellular types similar to other mammals. The morphometric data of the study area were statistically evaluated using the Student's $t$-test. Therefore, ovarian histomorphometric analysis are very important to infer with greater certainty about the reproduction of a species. Thus, it was observed that females of $D$. cinerea exhibit two reproductive peaks, that is, they can give
\end{abstract}

\footnotetext{
${ }^{1}$ Received on August 4, 2016.

Accepted for publication on July 17, 2017.

${ }^{2}$ Área de Morfologia, Departamento de Morfologia e Fisiologia Animal, Universidade Federal Rural de Pernambuco (UFRPE), Rua Dom Manoel de
} 
birth either at the end of dry periods or from the beginning to the middle of the rainy season. The main feature observed in the ovary of this species, found in the Atlantic Forest area of the state of Pernambuco, is the preparation of the ovarian cortex to ovulate in months of high rainfall throughout the year. Therefore, this species tries to adjust its reproductive period with the variations of the environmental conditions, so that the reproduction might occur during the period more favorable for the maintenance of their offspring.

INDEX TERMS: Reproductive stage, ovarian histomorphometry, Dermanura cinerea, Chiroptera, Phyllostomidae, Atlantic Forest, Pernambuco, bat, bimodal polyestry, ovary.

RESUMO.- [Análise do estágio reprodutivo e histomorfometria ovariana de Dermanura cinerea (Chiroptera: Phyllostomidae) em um fragmento de Mata Atlântica de Pernambuco, Nordeste do Brasil.] Esse estudo objetivou analisar o estágio reprodutivo, histologia e morfometria do ovário de Dermanura cinerea em um fragmento de Mata Atlântica da Reserva Biológica de Saltinho (Pernambuco, Brasil). Foram utilizadas fêmeas adultas capturadas por redes de neblina, de modo que as coletas ocorreram mensalmente, durante duas noites consecutivas de Junho/2014 a Novembro/2015. Os dados meteorológicos foram fornecidos pelo Instituto Nacional de Meteorologia e agrupados, juntamente com os dados reprodutivos, em seis períodos, sendo estes: período I (Junho a agosto/2014), período II (Setembro a novembro/2014), período III (Dezembro/2014 a fevereiro/2015) período IV (Março a maio/2015), período V (Junho a agosto/2015) e período VI (Setembro a novembro/2015). As fêmeas foram classificadas, de acordo com o estágio reprodutivo em: inativas, grávidas, lactantes e pós-lactantes. Das 25 fêmeas capturadas, foram selecionadas, para as análises histomorfométricas dos ovários, 10 fêmeas inativas, as quais foram eutanasiadas. Depois disso, os espécimes tiveram os seus ovários removidos, fixados, processados e inclusos em paraplast. Os cortes foram corados por Hematoxilina - Eosina e as lâminas histológicas produzidas foram submetidas às devidas análises em microscópio óptico. Cada tipo de folículo ovariano foi estimado de acordo com as características histológicas evidenciadas para outros mamíferos. Nas análises morfométricas, considerou-se: a área do ovário (mensurada em milímetro quadrado), quantificação dos diferentes tipos de folículos ovarianos (primários unilaminar e multilaminar, antrais e maduros) e corpo lúteo, bem como foi medida a área de cada um desses diferentes tipos de folículos (mensurada em micrômetro quadrado). Os resultados indicaram a presença de 16 fêmeas inativas, 5 lactantes, 4 grávidas e nenhuma pós-lactante. As análises histológicas destacaram que os ovários de $D$. cinerea possui características, estruturas e tipos celulares padrões semelhantes ao dos demais mamíferos. Os dados morfométricos da área do ovário foram avaliados estatisticamente por meio do teste $t$ de Student. Assim, as análises histomorfométricas ovariana são de suma importância para inferir com maior segurança sobre a reprodução de uma dada espécie. Portanto, ficou constatado que as fêmeas de $D$. cinerea apresentam dois picos reprodutivos, isto é, podem parir no final de períodos secos ou do início para metade do período chuvoso. A principal característica observada no ovário dessa espécie, encontrada em área de Mata Atlântica do estado de Pernam- buco, foi a preparação do córtex ovariano para ovular em meses de elevados índices pluviométricos ao longo do ano. Logo, essa espécie procura ajustar seu período reprodutivo com as variações das condições ambientais, de forma que a reprodução ocorra em períodos mais favoráveis para manutenção da prole.

TERMOS DE INDEXAÇÃO: Estágio reprodutivo, histomorfometria ovariana, Dermanura cinerea, Chiroptera, Phyllostomidae, Mata Atlântica, Pernambuco, Brasil, morcego, poliestria bimodal, ovário.

\section{INTRODUCTION}

In the Order Chiroptera, the patterns and strategies reproductive are diverse and consist of the most varied among mammals (Peracchi et al. 2006). These strategies and patterns are determined by several factors, such as: temperature, precipitation, habitat, Family, Genus and even the same species may present different reproductive patterns in different locations (Racey \& Entwistle 2000, Beguelini et al. 2013a, Godoy et al. 2014). Four types of reproductive patterns are described for bats that inhabit the Neotropical region: seasonal monoestry, seasonal polyestry, non-seasonal polyestry and bimodal seasonal polyestry (Fleming et al. 1972, Willig 1985, Estrada \& Coates-Estrada 2001, Zortéa 2003).

In this way, species of bats that inhabit areas of the Neotropical region and that feed on fruits and insects, Kunz (1982) emphasized that births may occur at the end of September and beginning of October that correspond to the months which precede the first peak of rain, As well as births may occur later, between October and November. In addition, Fleming et al. (1972) and Heithaus et al. (1975) reinforce that the bimodal polyestrous pattern has been reported for frugivorous species with the occurrence of births during the rainy season, in which food was abundant, reinforcing the influence that the environmental conditions exert on the reproductive biology of these mammals (Ortêncio Filho et al. 2007). However, these verifications are currently relative and vary depending on different factors that should be analyzed in an individualized way.

Due to this, in Brazil, the reproductive aspects of the bats still present several incongruities, especially when considering the reproductive activity of females, because most of the studies are directed to the morphophysiology reproductive of males with emphasis on the testicles, epididymis (Beguelini et al. 2009, 2010, 2011, 2013a, 2013b, 2013c, 2013d, 2013e, 2015, 2016, Morais et al. 2013a, 2013b, 2014a, 2014b, Farias et al. 2014, Lima Junior et al. 2014, Notini et al. 2015) And accessory sex glands (Puga 
et al. 2013, 2014, 2016, Christante et al. 2015, Martins et al. 2015, 2016). However, approaches on the reproductive biology of females are limited and their reproductive pattern are defined based only on investigations of the external morphological characteristics of their body (dilated abdomen, visible nipples with secretion and the absence of hair around it) (Racey 1988, Gannon \& Willig 1992, Esbérard 2002). In other countries, there is some recent research on female gonadal histophysiology focusing on folliculogenesis and ovulation of different species of bats located in Colombia (Komar et al. 2007), China (Wang et al. 2008), Canada (Rintoul \& Brigham 2014), Mexico (Antonio-Rubio Porras-Gómez \& Moreno-Mendoza 2013) and India (Sastry \& Pillai 2013, Singh et al. 2015).

Thus, to define a reproduction pattern of a species only based on external morphological characteristics of the body makes the information about the reproductive biology limited, and it can sometimes lead to imprecise conclusions (Lima Junior et al. 2014), such a female that is inactive, according to external morphology, is not necessarily in ovarian inactivity. For this reason, it is very important to associate these findings with the histological and morphometric analysis of the gonads (Paula et al. 2002, Morais et al. 2013c, 2014a). In Brazilian territory, it is verified that there are no studies either about histology or ovarian morphometry related to the different species of bats, so that only a few investigations based on external morphology characteristics were carried out (Duarte \& Talamoni 2010, Bordignon \& França 2012).

Dermanura cinerea Gervais, 1856 is a frugivorous species and plays an important role as seed disperser. Moreover, this species belongs to the family Phyllostomidae and subfamily Stenodermatinae. However, this species was previously known as Artibeus cinereus, but due to molecular studies, some changes occurred in the phylogeny of this group and currently Dermanura is considered a valid Genus (Solari et al. 2009, Reis et al. 2011). In Brazil, there are reports of its occurrence in the North, Northeast, Southeast and in the South. Furthermore, this species is widely distributed in areas of riparian forests and fragments of Atlantic Forest (Scultori et al. 2009, Reis et al. 2011).

Information about the reproductive pattern of $D$. cinerea is scarce, especially histological and morphometric data of the ovaries, which are non-existent. In view of these aspects, the present study aimed to analysis the reproductive condition and the ovarian histomorphometry of $D$. cinerea in a fragment of the Atlantic Forest of Pernambuco, correlating the reproductive data with monthly rainfall indices.

\section{MATERIALS AND METHODS}

Adult female bats of the species Dermanura cinerea were collected in the Biological Reserve of Saltinho (REBIO - Saltinho) (La-

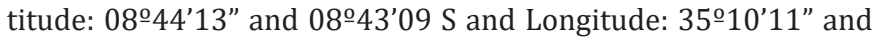
35011'02" W). This reserve consists of a Conservation Unit of Integral Protection composed by the Atlantic Forest (Rebio Saltinho 2003).

This study was approved by the Ethics Committee on Animal Use - CEUA of the Federal University of Pernambuco - UFPE (Protocol number: 23076.037360/2014 - 92) and all captures were authorized by the ICMBio - Instituto Chico Mendes de Conser- vação da Biodiversidade, with the following registration number on SISBIO - Sistema de Autorização e informação em Biodiversidade (№ 26531-3).

The animals were caught by 10 mist nets $(12 \mathrm{~m}$ long $\mathrm{x} 3 \mathrm{~m}$ high). All captures occurred monthly over eighteen months from July/2014 to November/2015, during two consecutive nights. The nets were set at 5:00 p.m. and remained open until 00:00 a.m. The total catch/effort ratio was $90720 \mathrm{~m}^{2}$.h. (Straube \& Bianconi 2002).

The National Institute of Meteorology - INMET (Instituto Nacional de Meteorologia/Seção de Observação e Meteorologia Aplicada - SEOMA), provided the data of temperature $\left({ }^{\circ} \mathrm{C}\right)$, relative humidity of the air (\%) and precipitation ( $\mathrm{mm})$.

Based on the monthly variation of precipitation, the analysis of the reproductive aspects of $D$. cinerea were organized in six periods of three months each: Period I (June, July and August/2014) - Representing the end of the rainy season; Period II (September, October and November/2014) - Indicating the beginning of the dry season, but some rain occurring in September and October; Period III (December/2014, January and February/2015) - Characteristic period of the dry season; Period IV (March, April and May/2015) - Corresponding to the beginning of the rainy season of the following year; Period V (June, July and August/2015) - regarding the end of the rainy season of the following year and Period VI (September, October and November/2015) - Corresponding to the beginning of the dry season.

The reproductive stage of females was determined based on the characteristics of the external morphology of their body, so that they were classified into four groups: Inactive - I (When they did not have apparently visible nipples, non-dilated abdomen and notoriously the absence of fetus); Pregnant - P (When the abdomen was raised and prominent); Lactating - L (When the nipples were perceptibly secreting, as well as when the furry area around the nipples were absent); and Postlactating - PL (If they were not producing secretion through the nipples, besides having little hair around the breasts) (Racey 1988, Gannon \& Willig 1992, Esbérard 2002).

The animals selected for histomorphometric analysis were euthanized. First of all, the animals were anesthetized with sodium pentobarbital at a concentration of $40 \mathrm{mg} \mathrm{kg}-1$ intraperitoneally, followed by a saturated solution of potassium chloride 40 $\mathrm{mg} / \mathrm{kg}^{-1}$ (Morais et al. 2013b).

10 inactive females were selected for the histomorphometric analysis of the ovaries. After euthanasia, the specimens were dissected and their ovaries were removed. A small incision was made with a scalpel in the abdomen towards the inguinal region. Thus, there was divulsion of the underlying tissue until these organisms were exposed and, consequently, collected.

The ovaries were fixed during 24 hours by immersion in $10 \%$ neutral buffered formalin (NBF), preserved in ethanol at $70 \%$ with $5 \%$ glycerin. Subsequently, the organs were processed according to routine histological technique (Behmer et al. 1976, Rieder \& Schmidt 1987), included in blocks of Paraplast and cut into $4 \mu \mathrm{m}$ thickness. It was performed semi-serial cuts with interval of $40 \mu \mathrm{m}$ between a cut and another one. Furthermore, the tissue preparations were stained with hematoxylin and eosin (HE) and analyzed by light microscopy.

The distinction of the different types of ovarian follicles found in $D$. cinerea were estimated based on the histological characteristics observed and already described for other mammals, since the bats present growth and development similar to the other animals belonging to the Class Mammalia (Bernard 1980, Crichton \& Krutzsch 2000, Dorlikar et al. 2013). Thus, initially there is a Primordial Follicle, which exhibit a single layer of flat cells and when these cells assume a cubic shape, they will originate the 
Unilaminar Primary Follicle. When follicular cells multiply and form a granular layer, they will originate the Multilaminar Primary Follicle (Preantral Follicle). Subsequently, the follicles grow and Occurs the agglomeration of the follicular fluid between the follicular cells, forming the Antrum, giving rise to the secondary follicle (Antral Follicle), this one grows more than others and reaching its highest stage of development, it becomes the mature follicle (Preovulatory or Graafian Follicle). After the ovulation process, there is a formation of an endocrine gland called Corpus Luteum (Parrott \& Skinner 2000, Hutt et al. 2006, Figueiredo et al. 2008, Martins et al. 2008, Dorlikar et al. 2013).

In the morphometric analysis were considered: The Ovarian Area (OA), which was measured in square millimeters $\left(\mathrm{mm}^{2}\right)$; The quantification of the different types of ovarian follicles (Unilaminar and Multilaminar Primary Follicles, Antral and Matures or Graafian Follicles) as well as the area of occupation of these follicles in square micrometers $\left(\mu \mathrm{m}^{2}\right)$. In addition, the number of corpus luteum was quantified. The histological slides were photographed by the software Motic Images Plus 2.0. For this, a camera was coupled between a computer and an optical microscope. The slides used for the measurement of the $\mathrm{OA}$ and quantification of the follicles were photographed at $40 \mathrm{x}$ magnification, while for the measurement of the area of each follicle the slides were photographed at $100 \mathrm{x}$ magnification. 10 photomicrographs per animal were used for each parameter measured. The images were captured in an orderly direction from the left border to the right edge of the ovary present on each histological slide. So, before each capture the stage control allowed the movement of the histological slide in the horizontal plane of the mechanical stage which is composed of two axis ( $\mathrm{x}$ and $\mathrm{y}$ ) reference to two rulers (horizontal and vertical) and measured in millimeters ( $\mathrm{mm}$ ) allowing the location of structures present in the ovary, in order to avoid photographing the same types of ovarian follicles. All parameters considered were measured and counted by the software Image J.

The statistical analysis of the OA was performed from the results obtained in the morphometry, which were submitted to Student's $t$-test and analysis of variance (ANOVA) of the software SPSS (Statistical Package for the Social Sciences, SPSS Inc. Chicago, USA) version 15.0. So that the results achieved of each period were compared to each other. The values of $p<0.05$ were considered statistically significant.

\section{RESULTS}

From June 2014 to November 2015, 25 adult female bats of the species Dermanura cinerea were collected. All these bats were classified according to external morphology of their body and organized by month. In addition, there were more specimens captured in July/2014 (n=11) (Fig.1).

Considering the reproductive stage in association with the periods, the following results were obtained: Period I ( $\mathrm{I}=10$ and $\mathrm{L}=04$ ), Period II ( $\mathrm{I}=02)$, Period III ( $\mathrm{L}=01$ and $\mathrm{P}=01)$, Period IV ( $\mathrm{I}=02$ and $\mathrm{P}=02)$, Period V ( $\mathrm{I}=01)$ and Pe$\operatorname{riod} \mathrm{VI}(\mathrm{I}=01$ and $\mathrm{P}=01)$. Thus, there was no capture of any postlactating female.

A higher occurrence of lactating females was observed in July/2014. Whereas, the lowest proportion of lactating and pregnant females occurred in the month of February/2015. During the months of April/2015 and November/2015 there was capture of pregnant females as well (Fig.1).

The rainfall índices were quite variable between the

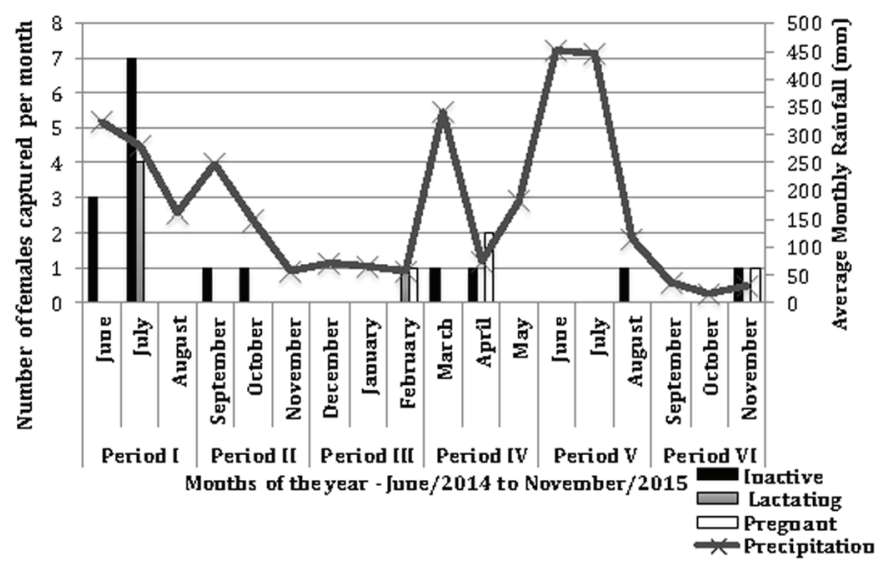

Fig.1. Relation between monthly precipitation, number of specimens and reproductive stage of females of Dermanura cinerea collected from June/2014 to November/2015 in an Atlantic Forest fragment in the Biological Reserve of Saltinho, Pernambuco, Brazil.

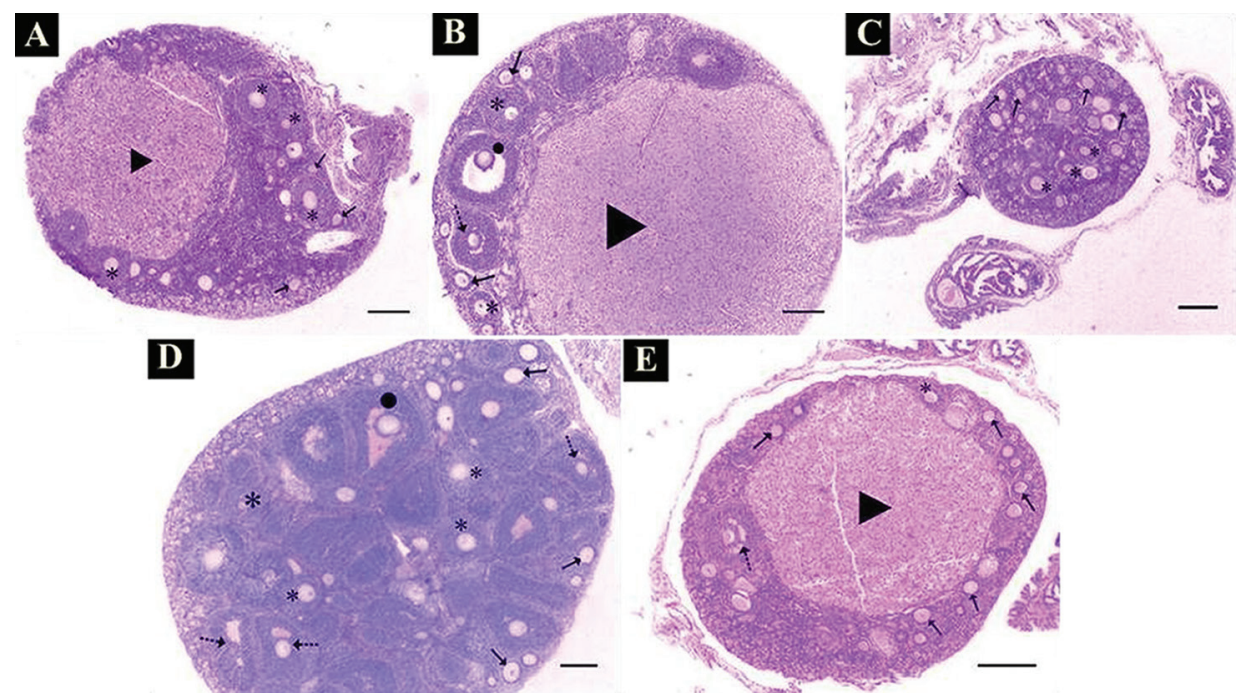

Fig.2. Ovaries of Dermanura cinerea. Observe the ovarian follicles at different stages of maturation (Arrow: Unilaminar primary follicle; Black asterisk: Multilaminar primary follicle; Dotted arrow: Antral or secondary follicle; Black dot: Mature follicle, Graafian or preovulatory) and corpus luteum (Arrowhead) per period (A) Period I; (B) Period II; (C) Period IV; (D) Period V; (E) Period VI. HE, obj.40x. Bar $=200 \mu \mathrm{m}$. 
months of the periods considered, while the temperature showed a slight variation $\left(24.0-27.4^{\circ} \mathrm{C}\right)$.

In addition to the observations based on the reproductive stage of $D$. cinerea, a histological analysis of the ovaries was also carried out. However, the Period III has no representation in the histomorphometric analysis of the ovaries, due to the fact that from December/2014 to February/2015 only pregnant and lactating females were captured, and for this analysis were considered only inactive females.

According to histological analysis, it was verified that this species has ovaries symmetry and mono-ovulates, and their shape varies from circular to ellipsoid. Furthermore, the surface exhbit simple cuboidal epithelium, and just below it, the tunica albuginea composed by dense connective tissue. Underlying this tunic was observed the cortical region, containing ovarian follicles at different stages of maturation. Internally, the medullar region is found, which it is formed by loose connective tissue (Fig.2).

The following types of follicles were identified: Unilaminar primary, Multilaminar primary, Antral and Graafian follicles (preovulatory or matures) and the Corpus luteum as well. The unilaminar and multilaminar primary follicles were present in all inactive bats from all periods considered, while the antral, matures and corpus luteum varied according to the period (Table 2). Therefore, the presence of the corpus luteum indicates the occurrence of ovulation and in those bats that were observed the presence of that structure, it always occupied the most part in the ovary (Fig.2).

In the morphometric analysis, the average of ovarian area (OA) that was obtained in each period was compared to each other and the statistical results revealed significant di- fferences in most of the comparisons (Table 1). The highest mean of OA occurred in Period V (June to August/2015) and the lowest mean was in the Period IV (March to May/2015) (Fig.3). The lowest OA (0.2) coincides with the period of occurrence of pregnant females (Period IV) (Fig.1).

The unilaminar and multilaminar primary follicles, as well as the antral and mature follicles, presented largest area during period $\mathrm{V}$ (Table 3) corresponding to the months that there was the highest OA. In addition, in this period the presence of corpus luteum was not identified, but there was the presence of graafian follicles (Tables 2 and 3 ) and it was the period that exhibited the highest rainfall

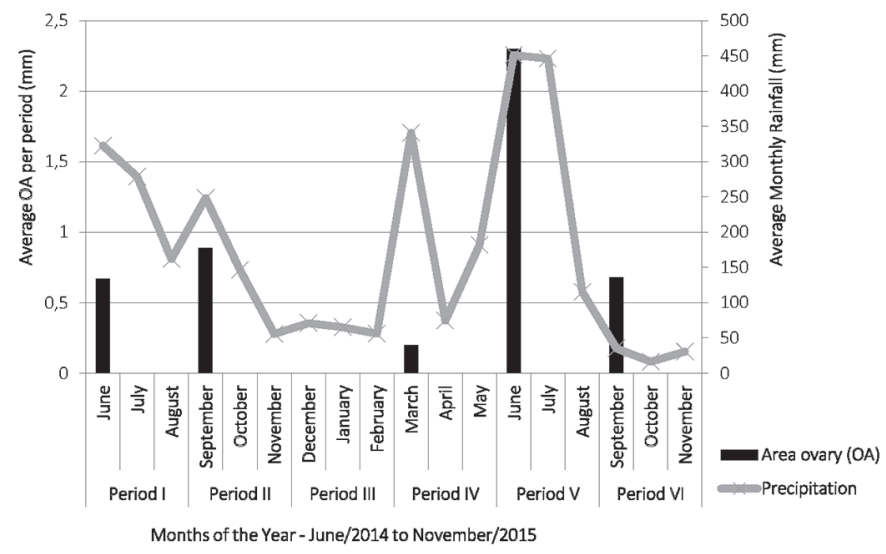

Fig.3. Relationship between the means of the monthly rainfall $(\mathrm{mm})$ and the arithmetic means of the ovarian area (OA) of Dermanura cinerea per period, collected from June/2014 to November/2015 in an Atlantic Forest fragment in the Biological Reserve of Saltinho, Pernambuco, Brazil.

Table 1. Mean and standard deviation of the ovarian area (OA)* of Dermanura cinerea collected between june/2014 to november/2015 at an Atlantic Forest fragments in the Biological Reserve of Saltinho, Pernambuco, Brazil

\begin{tabular}{|c|c|c|c|c|c|c|}
\hline Parameter & Period I & Period II & Period IV & Period V & Period VI & $\begin{array}{c}\mathrm{P} \text { value } \\
\mathrm{OA}^{* *}\end{array}$ \\
\hline $\mathrm{OA}$ & $0.66 \pm 0.24$ & $0.89 \pm 0.70$ & $0.20 \pm 0.11$ & $2.30 \pm 0.11$ & $0.68 \pm 0.03$ & $\begin{array}{l}0.173^{\mathrm{a}} \\
0.001^{\mathrm{b}} \\
0.001^{\mathrm{c}} \\
0.745^{\mathrm{d}} \\
0.001^{\mathrm{e}} \\
0.001^{\mathrm{f}} \\
0.188^{\mathrm{g}} \\
0.001^{\mathrm{h}} \\
0.001^{\mathrm{i}} \\
0.001^{\mathrm{j}}\end{array}$ \\
\hline
\end{tabular}

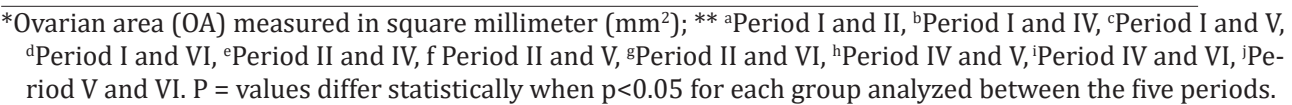

Table 2. Number of ovarian follicles types in different maturation stages and corpus luteum of Dermanura cinerea collected between june/2014 to november/2015 at an Atlantic Forest fragments in the Biological Reserve of Saltinho, Pernambuco, Brazil

\begin{tabular}{|c|c|c|c|c|c|c|c|c|c|c|c|c|c|c|c|}
\hline \multirow[t]{2}{*}{ Types of follicles } & \multicolumn{3}{|c|}{ Period I } & \multicolumn{3}{|c|}{ Period II } & \multicolumn{3}{|c|}{ Period IV } & \multicolumn{3}{|c|}{ Period V } & \multicolumn{3}{|c|}{ Period VI } \\
\hline & Jun & Jul & Aug & Sept & Oct & Nov & Mar & Apr & May & Jun & Jul & Aug & Sept & Oct & Nov \\
\hline Unilaminar & 2 & 35 & & 3 & 6 & & 7 & 11 & & & & 12 & & & 7 \\
\hline Multilaminar & 6 & 11 & & 1 & 4 & & 3 & 2 & & & & 9 & & & 4 \\
\hline Antral & 2 & 0 & & 1 & 1 & & 2 & 0 & & & & 8 & & & 1 \\
\hline Graafian & 0 & 0 & & 0 & 1 & & 1 & 0 & & & & 1 & & & 0 \\
\hline Corpus luteum & 1 & 4 & & 1 & 1 & & 0 & 0 & & & & 0 & & & 1 \\
\hline
\end{tabular}


Table 3. Arithmetic mean of the area* of each type of ovarian follicle of Dermanura cinerea collected between june/2014 to november/2015 at an Atlantic Forest fragments in the Biological Reserve of Saltinho, Pernambuco, Brazil

\begin{tabular}{|c|c|c|c|c|c|c|c|c|c|c|c|c|c|c|c|}
\hline \multirow[t]{2}{*}{ Follicles } & \multicolumn{3}{|c|}{ Period I } & \multicolumn{3}{|c|}{ Period II } & \multicolumn{3}{|c|}{ Period IV } & \multicolumn{3}{|c|}{ Period V } & \multicolumn{3}{|c|}{ Period VI } \\
\hline & Jun & Jul & $\overline{\text { Aug }}$ & Sept & Oct & Nov & Mar & Apr & May & Jun & Jul & Aug & Sept & Oct & Nov \\
\hline Unilaminar & 2152.400 & 2552.904 & & 574.384 & 4960.704 & & 866.662 & 803.943 & & & & 5627.131 & & & 1577.047 \\
\hline Multilaminar & 7883.558 & 7668.148 & & ** & 19887.449 & & 10448.000 & 3108.088 & & & & 20357.935 & & & 8774.373 \\
\hline Antral & 26308.560 & $* *$ & & 15322.832 & 27226.080 & & 19075.947 & ** & & & & 57956.640 & & & 22460.080 \\
\hline Graafian & $* *$ & $* *$ & & $* *$ & 60041.120 & & 26639.240 & $* *$ & & & & 105613.440 & & & $* *$ \\
\hline
\end{tabular}

* Area of follicles measured in square micrometer $\left(\mu \mathrm{m}^{2}\right),{ }^{* *}$ Absent follicles.

indices among all the periods considered, corresponding in the study area to the final months that compose the rainy season.

\section{DISCUSSION}

During the reproductive period, lactation is the most energy-intensive process (Loudon \& Racey 1987). Thus, the occurrence of Dermanura cinerea lactating females in July and February reveals a reproductive strategy of this species, because the availability of food is an important factor in determining the ability of females to allocate energy for reproduction and where there is plenty of food throughout the year. Therefore, the animals may be able to start reproduction at any time (Thompson 1992).

Linked to this information, the amount of energy during the period of pregnancy is lower when compared to the amount of energy spent during the lactation period (Racey \& Entwistle 2000). Therefore, it was observed a higher occurrence of lactating females in the period of higher rainfall index and higher incidences of pregnant during months in which there was a lower precipitation, due to the reason the precipitation is directly related to food availability for frugivorous species, which they get energy for their maintenance and reproductive activities (Fleming et al. 1972, Heithaus et al. 1975).

In view of this, what is verified is that females of $D$. $c i$ nerea can give birth either at the end of the dry period or from the beginning to the middle of the rainy season due to a greater availability of resources that might guarantee energy for the lactation and maintenance of their offspring. Furthermore, the annual reproductive patterns of these females exhibit a relationship with the rainfall indexes quite narrowly, such that the different adult species avoid weaning their pups during periods of great environmental stress (Willig 1985).

The presence of the corpus luteum and the absence of mature follicle, verified by histological analysis, in the months that there were occurrences of lactating and pregnant females reinforce the indication that there was ovulation in the considered periods to enable a possible pregnancy. Thus, the corpus luteum formed after ovulation, consists of a temporary endocrine gland that is related to the production of progesterone, which prepares the uterus to receive the embryo, as well as it contributes to the maintenance of this organ during the gestational period. On the other hand, if pregnancy does not occur, this gland will regress (Waelchli et al. 1994, Bertan et al. 2006).

In addition, the ovarian follicles reach the final stages of maturation and, consequently, after ovulation it gives rise to corpus luteum, induced by the release of luteinizing hormone. Thus, the size and the quantity of follicles in the ovary show variations that are related to the pattern of follicular development of each species. (Nascimento et al. 2003).

Moreover, the high averages related to the morphometry provide greater inferences about the reproductive capacity of females of $D$. cinerea during the months from June to August/2015. This indicates a possible preparation of the ovarian cortex for maturation of the follicles during the months of high rainfall. Therefore, the events of the annual reproductive cycle of this species may be correlated with an ovarian dynamic through variations without follicular growth (Komar et al. 2007).

The significant results found for $D$. cinerea related to ovarian morphometry evidence once again that this type of analysis provides reliable data about the reproductive capacity of the animal, in other words, whether it is active or not, demystifying erroneous and limited conclusions only by visual analysis of external morphology of the body, because some studies about bat reproduction consider females which are neither pregnant nor lactating, as inactive (Bredt et al. 1999, Gomes \& Uieda 2004, Ortêncio Filho et al. 2007). Therefore, as demonstrated in this study, there were variations between the groups, because all the females used in the morphometry were inactive according to their external morphology. However, there were high differences in the area of ovary and follicles, even all being classified in the same reproductive stage.

\section{CONCLUSIONS}

According to these information, it was observed that females of Dermanura cinerea, in the study area considered, have more than one reproductive peak. Moreover, from the information presented, they prefer to ovulate in periods of higher rainfall. Thus, they can give birth at the end of the dry season or from the beginning to the middle of the rainy season due to a greater availability of resources that might guarantee energy for lactation and the maintenance of their offspring.

Therefore, it can be inferred that $D$. cinerea exhibit at the Atlantic Forest area of the state of Pernambuco, a bimodal polyestrous pattern, which has already been reported for this same species in the states of São Paulo and Sergipe - Brazil (Simmons \& Voss 1998, Scultori et al. 2009, Rocha et al. 2010).

Acknowledgements.- The first author would like to thank CAPES - Coordenação de Aperfeiçoamento de Pessoal de Nível Superior - for the scholarship granted and the Reserva Biológica de Saltinho, Pernambuco, for allowing the captures of the bats. 


\section{REFERENCES}

Antonio-Rubio N.R., Porras-Gómez T.J. \& Moreno-Mendoza N. 2013. Identification of cortical germ cells in adult ovaries from three Phyllostomid bats: Artibeus jamaicensis, Glossophaga soricina and Sturnira lilium. Reprod. Fertil. Dev. 25:825-836.

Beguelini M.R., Moreira P.R.L., Faria K.C., Marchesin S.R.C. \& Morielle-Versute E. 2009. Morphological characterization of the testicular cells and seminiferous epithelium cycle in six species of neotropical bats. J. Morphol. 270:943-953.

Beguelini M.R., Sergio B.F.S., Leme F.L.J., Taboga S.R. \& Morielle-Versute E. 2010. Morphological and morphometric characteristics of the epididymis in the Neotropical bats Eumops glaucinus and Molossus molossus (Chiroptera: Molossidae). Chirop. Neotrop. 16(2):769-779.

Beguelini M.R., Puga C.C.I., Taboga S.R. \& Morielle-Versute E. 2011. Ultrastructure of spermatogenesis in the white-lined broad-nosed bat, Platyrrhinus lineatus (Chiroptera: Phyllostomidae). Micron 42:86-599.

Beguelini M.R., Puga C.C.I., Martins F.F., Betoli A.H.S., Taboga S.R. \& Morielle-Versute E. 2013a. Morphological Variation of Primary Reproductive Structures in Males of Five Families of Neotropical Bats. Anat. Rec. 296:156-167.

Beguelini M.R., Puga C.C.I., Taboga S.R. \& Morielle-Versute E. 2013b. Annual reproductive cycle of males of the flat-faced fruit-eating bat, Artibeus planirostris (Chiroptera: Phyllostomidae). Gen. Comp. Endocrinol. 185:80-89.

Beguelini M.R., Taboga S.R. \& Morielle-Versute E. 2013c. Ultrastructural characteristics of the spermatogenesis during the four phases of the annual reproductive cycle of the black Myotis bat, Myotis nigricans (Chiroptera: Vespertilionidae). Microsc. Res. Tech. 76:1035-1049.

Beguelini M.R., Goes R.M., Taboga S.R. \& Morielle-Versute E. 2013d. Two periods of total testicular regression are peculiar events of the annual reproductive cycle of the black Myotis bat, Myotis nigricans (Chiroptera: Vespertilionidae). Reprod. Fertil. Dev. 26:834-846.

Beguelini M.R., Bueno L.M., Caun D.L., Taboga S.R. \& Morielle-Versute E. 2013e. Ultrastructure of spermatogenesis in the short-tailed fruit bat, Carollia perspicillata (Chiroptera: Phyllostomidae: Carollinae). J. Morphol. 275(1):111-123.

Beguelini M.R., Goes R.M., Rahal P., Morielle-Versute E. \& Taboga S.R. 2015. Impact of the processes of total testicular regression and recrudescence on the epididymal physiology of the bat Myotis nigricans (Chiroptera: Vespertilionidae). PLoS One 10(6):e0128484.

Beguelini M.R., Puga C.C., Morielle-Versute E. \& Taboga S.R. 2016. Comparative analysis of the male reproductive accessory glands of bats Noctilio albiventris (Noctilionidae) and Rhynchonycteris naso (Emballonuridae). J. Morphol. 277(11):1459-1468.

Behmer O.A., Tolosa E.M.C. \& Neto A.G.F. 1976. Manual de Técnicas para Histologia Normal e Patológica. Edart, Universidade de São Paulo, São Paulo. 239p.

Bernard R.T.F. 1980. Female reproductive anatomy and development of ovarian follicles in Miniopterus fraterculus. S. Afr. J. Zool. 15:111-116.

Bertan C.M., Binelli M., Madureira E.H. \& Traldi A.S. 2006. Mecanismos endócrinos e moleculares envolvidos na formação do corpo lúteo e na luteólise: revisão de literatura. Braz. J. Vet. Res. Anim. Sci. 43(6):824-840.

Bordignon M.O. \& França A.O. 2012. Reproduction of the greater bulldog bat Noctilio leporinus (Chiroptera: Noctilionidae) in a mangrove area in southern Brazil. Biota Neotrop. 12(4):62-67.

Bredt A., Uieda W. \& Magalhães E.D. 1999. Morcegos cavernícolas da região do Distrito Federal, centro-oeste do Brasil (Mammalia, Chiroptera). Revta Bras. Zool. 16(3):731-770.

Christante C.M., Beguelini M.R., Puga C.C., Negrin A.C., Morielle-Versute E., Vilamaior P.S. \& Taboga S.R. 2015. Structure, histochemistry and seasonal variations of the male reproductive accessory glands in the Pallas's mastiff bat, Molossus molossus (Chiroptera: Molossidae). Reprod. Fertil. Dev. 27(2)313-322.

Crichton E.G. \& Krutzsch P.H. 2000. Reproductive Biology of Bats. Academic Press, San Diego, CA. 510p.

Dorlikar A.V., Dhamani A.A., Charde P.N. \& Mohite A.S. 2013. Morphomet- ric and histoarchitectural changes in the ovary of Pteropus giganteus (Brunnich) during various phases of reproductive cycle. Int. J. Mol. Zool. 3:32-41.

Duarte A.P.G. \& Talamoni S.A. 2010. Reproduction of the large fruit-eating bat Artibeus lituratus (Chiroptera: Phyllostomidae) in a Brazilian Atlantic forest area. Mamm. Biol. 75(4):320-325.

Esbérard C.E.L. 2002. Composição da colônia e reprodução de Molossus rufus em refúgio no sudeste do Brasil (Mammalia, Molossidae). Revta Bras. Zool. 19(4):1153-1160.

Estrada A. \& Coates-Estrada R. 2001. Species composition and reproductive phenology of bats in a tropical landscape at Los Tuxtlas, México. J. Trop. Ecol. 17:672-646.

Farias T.O., Notini A.A., Talamoni S.A. \& Godinho H.P. 2014. Testis Morphometry and Stages of the Seminiferous Epithelium Cycle in an Epididymal Sperm-storing Neotropical Vespertilionid, Myotis levis (Chiroptera). Anat. Histol. Embryol. 44(5):361-369.

Figueiredo J.R., Rodrigues A.P.R., Amorim C.A. \& Silva J.R.V. 2008. Manipulação de oócitos inclusos em folículos ovarianos pré-antrais, p.303327. In: Gonçalves P.B.D., Figueiredo J.R. \& Freitas V.J.F (Eds), Biotécnicas Aplicadas à Reprodução Animal. 2aㅡ ed. Roca, São Paulo.

Fleming T.H., Hooper E.T. \& Wilson D.E. 1972. Three central American bat communities: structure, reproductive cycles and movement patterns. Ecology 53:555-569.

Gannon M.R. \& Willig M.R. 1992. Bat reproduction in the Luquillo Experimental Forest of Puerto Rico. Southwest Naturalist 37(4):414-419.

Godoy M.S.M., Carvalho W.D. \& Esbérard C.E.L. 2014. Reproductive biology of the bat Sturnira lilium (Chiroptera, Phyllostomidae) in the Atlantic Forest of Rio de Janeiro, southeastern Brazil. Braz. J. Biol. 74(4):913922.

Gomes M.N. \& Uieda W. 2004. Abrigos diurnos, composição de colônias, dimorfismo sexual e reprodução do morcego hematófago Desmodus rotundus (E. Geoffroy) (Chiroptera, Phyllostomidae) no Estado de São Paulo, Brasil. Revta Bras. Zool. 21(3):629-638.

Heithaus E.R., Fleming T.H. \& Opler P.A. 1975. Foraging patterns and resource utilization in seven species of bats in a seasonal tropical forest. Ecology 56:841-854.

Hutt K.J., McLaughlin E.A. \& Holland M.K. 2006. KIT/KIT Ligand in mammalian oogenesis and folliculogenesis: roles in rabbit and murine ovarian follicle activation and oocyte growth. Biol. Reprod. 75:421-433.

Komar C.M., Zacharachis-Jutz F., Cretekos C.J., Behringer R.R. \& Rasweiler J.J. 2007. Polarized ovaries of the long-tongued bat, Glossophaga soricina: a novel model for studying ovarian development, folliculogenesis, and ovulation. Anat. Rec. 290:1439-1448.

Kunz T.H. 1982. Ecology of reproduction, p.57-93. In: Kunz T.H. (Ed.), Ecology of Bats. Plenum Press, New York.

Lima Junior N.B., Arandas M.J.G., Marinho K.S.N., Aguiar Júnior F.C.A., Pontes A.R.M. \& Santos K.R.P. 2014. Histomorfometria testicular do morcego Phyllostomus discolor (Chiroptera: Phyllostomidae) em áreas de Mata Atlântica de Pernambuco. Braz. J. Vet. Res. Anim. Sci. 51(3):263270.

Loudon A.S.I. \& Racey P.A. 1987. Reproductive Energetics in Mammals. Symposia of the Zoological Society of London, n.57. 371p.

Martins F.S., Silva J.R.V., Rodrigues A.P.R. \& Figueiredo J.R. 2008. Fatores reguladores da foliculogênese em mamíferos. Revta Bras. Reprod. Anim. 32(1):36-39.

Martins F.F., Puga C.C., Beguelini M.R., Morielle-Versute E., Vilamaior P.S. \& Taboga S.R. 2015. Comparative analysis of the male reproductive accessory glands of bat species from the five Brazilian Subfamilies of the family Phyllostomidae (Chiroptera). J. Morphol. 276(4):470-480.

Martins F.F., Beguelini M.R., Puga C.C., Morielle-Versute E., Vilamaior P.S. \& Taboga S.R. 2016. Morphophysiology and ultrastructure of the male reproductive accessory glands of the bats Carollia perspicillata, Glossophaga soricina and Phyllostomus discolor (Chiroptera: Phyllostomidae). Acta Histochem. 118(6):640-651.

Morais D.B., Oliveira LC., Cupertino M.C., Freitas K.M., Freitas M.B.D., Paula T.A.R. \& Matta S.L.P. 2013a. Organization and seasonal quantification 
of the intertubular compartment in the bat Molossus molossus (Pallas, 1776) testis. Microsc. Res. Tech. 76:94-101.

Morais D.B., Paula T.A.R., Barros M.S., Balarini M.K., Freitas M.B.D. \& Matta S.L.P. 2013b. Stages and duration of the seminiferous epithelium cycle in the bat Sturnira lilium. J. Anat. 222(3):372-379.

Morais D.B., Cupertino M.C., Goulart L.S., Freitas K.M., Freitas M.B.D., Paula T.A.R. \& Matta S.L.P., 2013c. Histomorphometric evaluation of the Molossus molossus (Chiroptera, Molossidae) testis: the tubular compartmentand indices of sperm production. Anim. Reprod. Sci. 140(3):268278.

Morais D.B., Barros M.S., Freitas M.B.D., Paula T.A.R. \& Matta S.L.P. 2014a. Histomorphometric characterization of the intertubular compartment in the testes of the bat Sturnira lilium. Anim. Reprod. Sci. 147(3):180-186.

Morais D.B., Barros M.S., Paula T.A.R., Freitas M.B.D., Gomes M.L.M. \& Matta S.L.P. 2014b. Evaluation of the cell population of the seminiferous epithelium and spermatic indexes of the bat Sturnira lilium (Chiroptera: Phyllostomidae). PloS One 9(7):e101759.

Nascimento A.A., Pinheiro N.L., Sales A. \& Viana J.H.M. 2003. Correlação morfométrica do ovário de fêmeas bovinas em diferentes estádios reprodutivos. Braz. J. Vet. Res. Anim. Sci. 40(2):126-132.

Notini A.A., Farias T.O., Talamoni S.A. \& Godinho H.P. 2015 Annual male reproductive activity and stages of the seminiferous epithelium cycle of the large fruit-eating Artibeus lituratus (Chiroptera: Phyllostomidae). Zoologia 32(3):195-200.

Ortêncio Filho H., Reis N.R., Pinto D. \& Vieira D.C. 2007. Aspectos reprodutivos de Artibeus lituratus (Phyllostomidae) em fragmentos florestais na região de Porto Rico, Paraná, Brasil. Chiropt. Neotrop. 13(2):313-318.

Parrott J.A. \& Skinner M.K. 2000. Kit ligand on ovarian stromal cells: effects on theca cell recruitment and steroid production. Mol. Reprod. Dev. 55:55-64.

Paula T.A.R., Costa D.S. \& Matta S.L.P. 2002. Avaliação histológica quantitativa do testículo de capivaras (Hydrochoerus hydrochaeris) adultas. Biosci. J. 18(1):121-136.

Peracchi A.L., Lima I.P., Reis N.R., Nogueira M.R. \& Ortêncio Filho H. 2006. Ordem Chiroptera, p.153-230. In: Reis N.R., Peracchi A.L., Pedro W.A. \& Lima I.P. (Eds), Mamíferos do Brasil. Edifurb, Londrina.

Puga C.C., Beguelini M.R., Negrin A.C., Christante C.M., Morielle-Versute E., Vilamaior P.S. \& Taboga S.R. 2013. Structure, histochemistry and ultrastructure of the male reproductive accessory glands in the neotropical flat-faced fruit-eating bat Artibeus planirostris (Chiroptera: Phyllostomidae). Reprod. Fertil. Dev. 25(3):558-569.

Puga C.C., Beguelini M.R., Martins F.F., Falleiros L.R., Morielle-Versute E., Vilamaior P.S. \& Taboga S.R. 2014. Seasonal changes in the prostatic complex of Artibeus planirostris (Chiroptera: Phyllostomidae). Gen. Comp. Endocrinol. 197:33-42.

Puga C.C., Beguelini M.R., Morielle-Versute E., Vilamaior P.S. \& Taboga S.R. 2016. The effects of castration followed testosterone supplementation in prostatic complex of Artibeus planirostris (Chiroptera: Phyllostomidae). Tissue Cell 48(3):252-264.

Racey P.A. 1988. Reproductive assessment in bats, p.31-43. In: Kunz T.H. (Ed.), Ecological and Behavioral Methods for the Study of Bats. Smithsonian Institution Press, Washington, DC. 553p.
Racey P.A. \& Entwistle. A.C. 2000. Life-history and reproductive strategies of bats, p.363-414. In: Crichton E.G. \& Krutzch P.H. (Eds), Reproductive Biology of Bats. Academic Press, San Diego, CA.

Rebio Saltinho. 2003. Reserva Biológica de Saltinho. Plano de Manejo. IBAMA, Brasília.

Reis N.R., Peracchi A.L., Pedro W.A. \& Lima I.P. 2011. Mamíferos do Brasil. $2^{\underline{a}}$ ed. Universidade Estadual de Londrina, Londrina, 439p.

Rieder N. \& Schmidt K. 1987. Morphologische Arbeitsmethoden in der Biologie. Verlagsgesellschaft mbH, Germany.

Rintoul J.L. \& Brigham R.M. 2014. The influence of reproductive condition and concurrent environmental factors on torpor and foraging patterns in female big brown bats (Eptesicus fuscus). J. Comp. Physiol. B 184(6):777-787.

Rocha P.A., Mikalauskas J.S., Gouveia S.F., Silveira V.V.B. \& Peracchi A.L. 2010. Morcegos (Mammalia, Chiroptera) capturados no Campus da Universidade Federal de Sergipe, com oito novos registros para o estado. Biota Neotrop. 10(3):183-188.

Sastry M.S. \& Pillai S.B. 2013.Variations in the epithelial cords of the ovaries of a microchiropteran bat, Hipposideros speoris (Schneider) during reproductive cycle: An enzymic approach. J. Cell Anim. Biol. 7(11):132137.

Scultori C., Dias D. \& Peracchi A.L. 2009. Mammalia, Chiroptera, Phyllostomidae, Artibeus cinereus: First record in the state of Paraná, southern Brazil. Check List 5(2):325-329.

Simmons N.B. \& Voss R.S. 1998. The mammals of Paracou, French Guiana: a neotropical lowland rainforest fauna. Part I. Bats. Bull. Am. Mus. Nat. Hist. 273:1-219.

Singh A., Suragani M., Ehtesham N.Z. \& Krishna A. 2015. Localization of resistin and its possible roles in the ovary of a vespertilionid bat, Scotophilus heathi. Steroids 95:17-23.

Solari S., Hoofer S.R., Larsen P.A., Brown A.D., Bull R.J., Guerrero J.A., Ortega J., Carrera J.P, Bradley R.D. \& Baker R.J. 2009. Operational criteria for genetically defined species: analysis of the diversification of the small fruit-eating bats, Dermanura (Phyllostomidae: Stenodermatinae). Acta Chiropt. 11(2):279-288.

Straube F.C. \& Bianconi G.V. 2002. Sobre a grandeza e a unidade utilizada para estimar esforço de captura com utilização de redes-de-neblina. Chiropt. Neotrop. 8(1/2):150-152.

Thompson M.J.A. 1992. Roost philopatry in female pipistrelle bats Pipistrellus pipistrellus. J. Zool. 228:673-679.

Waelchli R.O., Känzig M., Döbeli M. \& Rüsch P. 1994. Condition of the uterine cervix in relation to cycle stage, plasma progesterone and estradiol - $17 \beta$ concentrations in the mare. Reprod. Dom. Anim. 29(6):404-410.

Wang Z., Liang B., Racey P.A., Wang Y.L. \& Zhang S.Y. 2008. Sperm storage, delayed ovulation, and menstruation of the female Rickett's big-footed bat (Myotis ricketti). Zool. Stud. 47(2):215-221.

Willig M.R. 1985. Reproductive patterns of bats from Caatingas and Cerrado biomes in northeastern Brazil. J. Mammal. 66:668-681.

Zortéa M. 2003. Reproductive patterns and feeding habits of three nectarivorous bats (Phyllostomidae: Glossophaginae) from the Brazilian Cerrado. Braz. J. Biol. 63(1):159-168. 